\title{
Enhancement of Host Resistance to Bacterial and Viral Infections by Lactobacillus casei
}

\author{
Hajime SAITo \\ Department of Microbiology and Immunology, Shimane Medical University, Izumo, Shimane, 693
}

(Received for publication, September 14, 1987)

Key words : Lactobacillus casei; immunopotentiator

Microorganisms such as Mycobacterium, Corynebacterium, and Streptococcus and their components enhance resistance to bacterial and viral infections $(6,7,16,18-$ $23)$; this effect being caused by the direct activation of macrophage functions or $\mathrm{T}$ or B cell-mediated macrophage activation $(3,9,16)$. Bloksma et al (4) reported that some lactobacilli, especially Lactobacillus plantarum, have a strong adjuvanticity on the antibody production to sheep erythrocyte and on delayed-type hypersensitivity. Kato et al (8) reported that Lactobacillus casei may induce macrophages that have potent antitumor activity against sarcoma 180 and L1210 leukemia.

The objective of the present study was to determine if Lactobacillus, especially $L$. case $i$ would enhance the host resistance to bacterial and viral infections induced in mice.

\section{ENHANCEMENT OF HOST RESISTANCE TO INFECTION WITH EXTRACELLULAR PARASITE BY L. CASEI}

The effects of $L$. casei on Pseudomonas aeruginosa infections in normal, dexamethasone-treated, and tumor-bearing mice were studied. The details have been reported elsewhere $(20,21)$.

Normal mice. Mice (ddY strain) were infected intraperitoneally (ip) with Pseudomonas aeruginosa $\left(8.8-11.0 \times 10^{6}\right.$ cells) on days 1, 7, 14 and 21 after the intraperitoneal injection of heat-killed $L$. casei $\left(2.8 \times 10^{8}\right.$ cells $)$. Survival rates for mice infected with $P$. aeruginosa on days 1,7 and 14 after the injection of $L$. casei were significantly higher (80, 70 and $50 \%$, respectively) than in the control mice but decreased to $20 \%$ in mice injected on day 21 . When the same experiment was done by giving an intravenous injection of $L$. casei, the number of survivors did not significantly differ from those in the control group. Seven and 14 days after the infection with $P$. aeruginosa, 10 and $30 \%$, respectively, of the mice had survived. When an intramuscular injection of $L$. casei was given, all of the mice died within $24 \mathrm{hr}$. In vivo killing activity of peritoneal exudate cells (PECs) from mice injected intravenously (iv) with heat-killed $L$. casei $\left(2.0 \times 10^{8}\right.$ cells $)$ against $P$. aeruginosa $\left(1.0 \times 10^{5}\right.$ 
cells) was determined $3 \mathrm{hr}$ after infection. PECs from $L$. casei-treated mice showed no killing activity on day 1 , but there was slight killing activity on day 7 , a maximum was reached on day 14 , and a reduction was seen on day 21 . In contrast, no killing activity of PECs from control mice was nil throughout the experiment. There was no significant difference between $L$. casei-treated mice and control mice with regard to the number of PECs and the percentages of macrophages and polymorphonuclear cells (PMNs) in PECs.

Dexamethasone-treated mice. Mice (ddY strain) were injected ip with dexamethasone in the dose of $0.04 \mathrm{mg}$ once daily for 3 days and $24 \mathrm{hr}$ after the last injection the mice were given ip heat-killed $L$. casei $\left(1.1 \times 10^{8}\right.$ cells) or saline (control). Seven days after the injection, the mice were infected ip with $P$. aeruginosa $\left(1.1 \times 10^{6}\right.$ cells $)$. Seven days after the induced infection, there were no survivors among the dexamethasone-treated mice whereas $50 \%$ of the mice given $L$. casei survived. The in vivo killing activity of PECs from dexamethasone-treated mice against $P$. aeruginosa $(1.0 \times$ $10^{5}$ cells) at $3 \mathrm{hr}$ after infection was lower than that of PECs from normal mice. When dexamethasone-treated mice were injected ip with heat-killed $L$. casei $(2.0 \times$ $10^{8}$ cells) 7 days before the intraperitoneal infection with $P$. aeruginosa, the reduced killing activity was markedly enhanced. The number of PECs $\left(1.7 \times 10^{6} \mathrm{cells} /\right.$ mouse) and the percentages of macrophages in the PECs (49.1\%) from dexametha-

Table 1. Effect of LC9018 on the resistance against $P$. aeruginosa in $\mathrm{S}-180$ bearing mice ${ }^{a)}$

\begin{tabular}{|c|c|c|c|c|c|}
\hline & Experiment & $\begin{array}{l}\text { Days after } \\
\text { tumor } \\
\text { graft }\end{array}$ & $\begin{array}{l}\text { Implantation } \\
\text { of } \\
\text { S-180 cells }\end{array}$ & $\begin{array}{c}\text { Treatment } \\
\text { with } \\
\text { LC9018 }\end{array}$ & $\begin{array}{l}\text { Percentage } \\
\text { of } \\
\text { survivors }\end{array}$ \\
\hline \multirow{9}{*}[\mathrm{I}]{} & \multirow{9}{*}{$\begin{array}{l}\text { LC9018 (ip) } \\
\text { Infection (iv) }\end{array}$} & \multirow{3}{*}{2} & - & - & 50 \\
\hline & & & + & - & 30 \\
\hline & & & + & + & 90 \\
\hline & & \multirow{3}{*}{7} & - & - & 20 \\
\hline & & & + & - & 20 \\
\hline & & & + & + & 50 \\
\hline & & \multirow{3}{*}{14} & - & - & 50 \\
\hline & & & + & - & 30 \\
\hline & & & + & + & 70 \\
\hline \multirow{9}{*}{ [II] } & \multirow{9}{*}{$\begin{array}{l}\text { LC9018 (iv) } \\
\text { Infection (ip) }\end{array}$} & \multirow{3}{*}{2} & - & - & 20 \\
\hline & & & + & - & 10 \\
\hline & & & + & + & 30 \\
\hline & & \multirow{3}{*}{7} & - & - & 20 \\
\hline & & & + & - & 0 \\
\hline & & & + & + & 50 \\
\hline & & \multirow{3}{*}{14} & - & - & 40 \\
\hline & & & + & - & 10 \\
\hline & & & + & + & 40 \\
\hline
\end{tabular}

a) Mice $(n=10)$ were given S-180 $\left(1 \times 10^{6}\right.$ cells $) 2,7$ or 14 days before and further intraperitoneally or intravenously LC9018 $(0.5 \mathrm{mg})$ once 3 days before the intravenous or the intraperitoneal challenge with $P$. aeruginosa $\left(7 \times 10^{6}\right)$. 
sone-treated mice increased $\left(2.1 \times 10^{7}\right.$ cells/mouse; macrophages $\left.59.5 \%\right)$ with the intraperitoneal administration of $L$. casei. However, there was no difference between the percentage of PMNs from mice given dexamethasone alone $(5.8 \%)$ and dexamethasone-treated $(5.7 \%)$ mice injected with $L$. casei.

Corticosteroids strongly suppress various functions of macrophages but do not affect the functions of $\mathrm{PMNs}(2,15)$. Thus, the enhancement of resistance of dexamethasone-treated mice to $P$. aeruginosa infection is probably due to restoration and enhancement of the dysfunctioning macrophage by the administration of L. casei.

Tumor-bearing mice. Sarcoma-180 bearing mice were given LC9018 (a heatkilled $L$. case $i$ preparation) once 3 days before challenge with $P$. aeruginosa. The resistance among S-180 bearing mice against Pseudomonas infection was lower than among the normal mice. The decreased resistance to infection in the $\mathrm{S}-180$ bearing mice was restored by injecting of LC9018 (Table 1). The number of organisms recovered from the liver of S-180 bearing mice pretreated ip or iv with LC9018 at $6 \mathrm{hr}$ after the infection was relatively less as compared with findings in the liver of S-180 bearing untreated control mice.

The enhancement of resistance of S-180 bearing mice pretreated with LC9018 against $P$. aeruginosa infection is probably due to restoration of depressed functions of the host reticulo-endothelial system in these mice, as induced by the implantation of S-180 tumor cells.

\section{ENHANCEMENT OF HOST RESISTANCE TO INFECTION WITH INTRACELLULAR PARASITE BY L. CASEI}

The enhancement of host resistance by Lactobacillus, particularly $L$. casei on experimental murine infection by Listeria monocytogenes, a facultative intracellular parasite was studied.

Role of Macrophages (22)

Protective effects of Lactobacillus spp. on Listeria infection. Mice were injected iv with Lactobacillus spp. 2 days before the intravenous challenge with Listeria monocytogenes EGD. A significant extension of the time of protection was observed in mice treated with $L$. casei than compared to those treated with other species of Lactobacillus (Table 2). Significant protective effects were also found in case of the intraperitoneal administration of $L$. casei, but not by the intramuscular or subcutaneous routes.

Protective activity of $\mathrm{L}$. casei against Listeria infection. The dose dependent effects of $L$. case $i$ on the protective activity against $L$. monocytogenes infection were also studied (Fig. 1). When $5.5 \times 10^{7}$ L. casei cells were given to mice (A) the protection was the most potent 2 days after $L$. casei administration and it decreased thereafter. When mice were given $1.1 \times 10^{9} \mathrm{~L}$. casei cells $(\mathrm{C})$, the enhanced resistance was seen at 3 to 21 days after the administration of $L$. casei. In contrast, when mice were given 2.1 $\times 10^{8} \mathrm{~L}$. casei cells $(\mathrm{B})$ the increased resistance was seen at $c a .2$ and 13 days after $L$. 
Table 2. Protective activity of Lactobacillus spp. against L. monocytogenes infection in mice ${ }^{a)}$

\begin{tabular}{|c|c|c|c|c|c|}
\hline \multirow{2}{*}{ Strain } & \multirow{2}{*}{ Expt. } & \multirow{2}{*}{$\begin{array}{l}\text { Dose } \\
\left(\times 10^{7}\right)\end{array}$} & \multicolumn{3}{|c|}{ Survivors/total (days) } \\
\hline & & & 3 & 5 & 7 \\
\hline \multirow[t]{2}{*}{ Control } & $\mathrm{I}$ & & $3 / 20$ & $0 / 20$ & $0 / 20$ \\
\hline & II & & $0 / 20$ & $0 / 20$ & $0 / 20$ \\
\hline \multirow[t]{2}{*}{ L. lactis ATCC 12315} & I & 3.4 & $5 / 19$ & $0 / 19$ & $0 / 19$ \\
\hline & II & 5.8 & $2 / 10$ & $0 / 10$ & $0 / 10$ \\
\hline \multirow[t]{2}{*}{ L. bulgaricus ATCC 11842} & I & 6.4 & $3 / 19$ & $0 / 19$ & $0 / 19$ \\
\hline & II & 5.0 & $1 / 10$ & $0 / 10$ & $0 / 10$ \\
\hline \multirow[t]{2}{*}{ L. acidophilus ATCC 19992} & $\mathrm{I}$ & 11.2 & $8 / 20$ & $1 / 20$ & $0 / 20$ \\
\hline & II & 2.8 & $1 / 10$ & $0 / 10$ & $0 / 10$ \\
\hline \multirow[t]{2}{*}{ L. salivarius ATCC 11742} & I & 2.2 & $6 / 20$ & $0 / 20$ & $0 / 20$ \\
\hline & II & 2.2 & $2 / 10$ & $0 / 10$ & $0 / 10$ \\
\hline \multirow[t]{2}{*}{ L. plantarum ATCC 8014} & I & 10.6 & $2 / 20$ & $0 / 20$ & $0 / 20$ \\
\hline & II & 3.8 & $1 / 10$ & $0 / 10$ & $0 / 10$ \\
\hline \multirow{2}{*}{ L. fermentum ATCC 9338} & I & 2.2 & $1 / 20$ & $0 / 20$ & $0 / 20$ \\
\hline & II & 5.6 & $0 / 10$ & $0 / 10$ & $0 / 10$ \\
\hline \multirow[t]{2}{*}{ L. cellobiosus ATCC 11739} & I & 2.2 & $6 / 20$ & $0 / 20$ & $0 / 20$ \\
\hline & II & 7.6 & $1 / 10$ & $0 / 10$ & $0 / 10$ \\
\hline \multirow[t]{2}{*}{ L. brevis ATCC 14869} & I & 11.0 & $5 / 19$ & $0 / 19$ & $0 / 19$ \\
\hline & II & 1.8 & $1 / 10$ & $0 / 10$ & $0 / 10$ \\
\hline \multirow[t]{2}{*}{ L. buchneri ATCC 4005} & I & 11.8 & $4 / 20$ & $0 / 20$ & $0 / 20$ \\
\hline & II & 1.3 & $2 / 10$ & $0 / 10$ & $0 / 10$ \\
\hline \multirow[t]{2}{*}{ L. casei YIT 0003} & I & 15.0 & $17 / 19^{b)}$ & $8 / 19^{b)}$ & $5 / 19 c)$ \\
\hline & II & 5.8 & $17 / 20^{b)}$ & $9 / 20^{b)}$ & $3 / 20$ \\
\hline Control & & & $0 / 10$ & $0 / 10$ & $0 / 10$ \\
\hline L. casei ATCC 393 & & 12.2 & $8 / 10^{b)}$ & $2 / 10$ & $1 / 10$ \\
\hline L. casei ATCC 7469 & & 11.4 & $10 / 10^{b)}$ & $0 / 10$ & $0 / 10$ \\
\hline L. casei YIT 0003 & & 10.2 & $8 / 10^{b)}$ & $2 / 10$ & $1 / 10$ \\
\hline L. casei YIT 0006 & & 8.4 & $10 / 10^{b)}$ & $1 / 10$ & $1 / 10$ \\
\hline L. casei YIT 0091 & & 11.8 & $9 / 10^{b)}$ & $3 / 10$ & $0 / 10$ \\
\hline L. casei YIT 0112 & & 7.2 & $10 / 10^{b)}$ & $2 / 10$ & $0 / 10$ \\
\hline L. casei YIT 9018 & & 7.6 & $8 / 10^{b)}$ & $1 / 10$ & $0 / 10$ \\
\hline
\end{tabular}

a) Optical density (at $540 \mathrm{~nm}$ ) of indicated Lactobacillus suspensions was adjusted to 1.0, and $0.2 \mathrm{ml}$ each was injected into mice 2 days before L. monocytogenes (first group of experiments, $1.1 \times 10^{6}$ : second group of experiments with $L$. case $i$ strains only, $1.0 \times 10^{6}$ ) infection.

b) Significantly different from controls at $P<0.01\left(\chi^{2}\right.$ test).

c) Significantly different from controls at $P<0.05$ ( $\chi^{2}$ test).

casei administration, in a two-peak pattern.

When mice were treated with $L$. casei cells 2 days before infection (A) in this series of experiments (Fig. 2), the growth of Listeria during 6 to $48 \mathrm{hr}$ after the infection was suppressed by the administration of either $1.1 \times 10^{7}$ or $1.1 \times 10^{8}$ cells of $L$. casei, but was accelerated when $1.1 \times 10^{9} \mathrm{~L}$. casei cells were given. When $L$. casei was given 13 days before the infection (B), the killing of Listeria in the liver during the first $6 \mathrm{hr}$ was significantly enhanced in mice given $1.1 \times 10^{9} \mathrm{~L}$. casei cells, but not with $1.1 \times 10^{7}$ L. casei cells.

A histopathological study was made of the liver of mice injected iv with either 

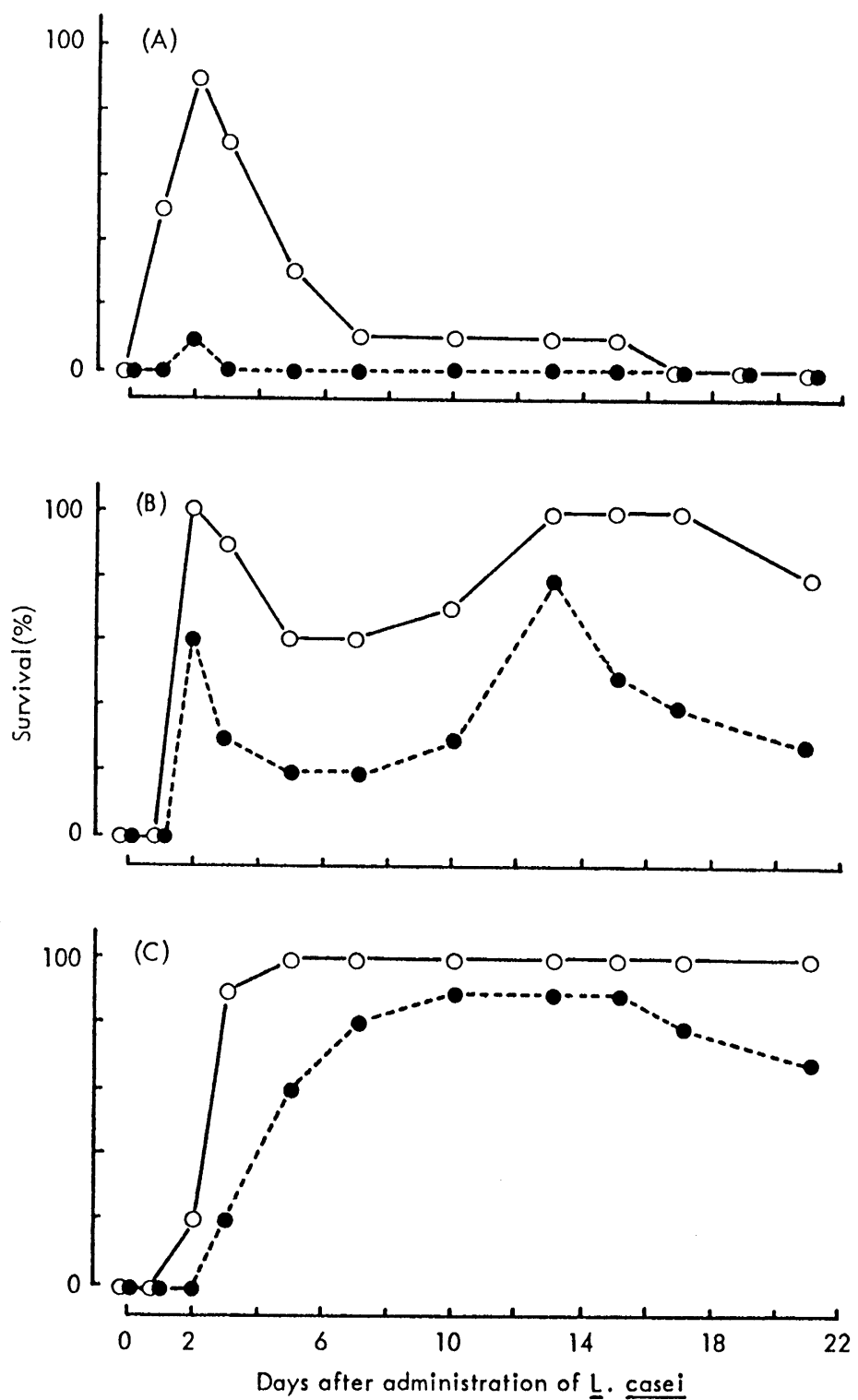

Fig. 1. Appearance and persistency of anti-L. monocytogenes action of $L$. casei. Mice were injected iv with (A) $5.5 \times 10^{7}$, (B) $2.8 \times 10^{8}$, and (C) $1.1 \times 10^{9}$ of viable $L$. casei cells on various days before $L$. monocytogenes infection and infected with $10^{6} \mathrm{~L}$. monocytogenes organisms. Survivors were counted at $3(\mathrm{O})$ and $7(0)$ days after infection. 


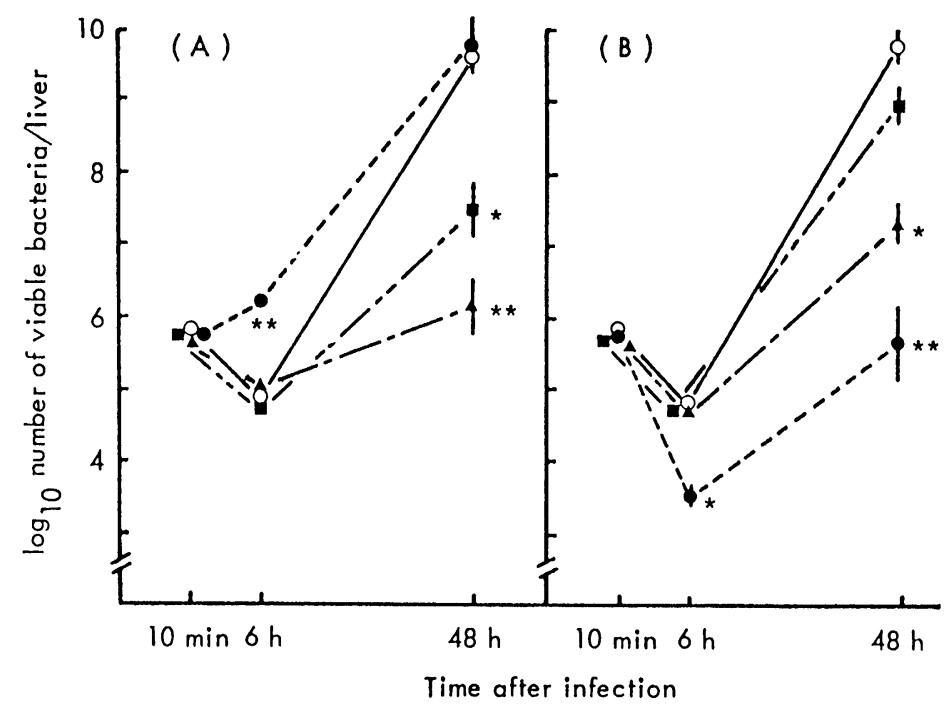

Fig. 2. Dose dependency of anti-L. monocytogenes action upon $L$. casei. Mice were given $1.1 \times 10^{7}(\boldsymbol{\square}), 1.1 \times 10^{8}(\mathbf{A})$, or $1.1 \times 10^{9}(\mathbf{O})$ of viable $L$. casei cells 2 (A) or $13(\mathrm{~B})$ days before infection, after which experimental and control $(O)$ mice were infected with $10^{6} \mathrm{~L}$. monocytogenes organisms. The fate of $L$. monocytogenes trapped in the liver was studied for up to $48 \mathrm{hr}$ after infection. Each symbol represents the mean \pm standard error $(n=3$ to 5$)$. The asterisks indicate significant difference between controls and L. caseitreated mice at levels of $P<0.05(*)$ and $P<0.01(* *)$ (Student's $t$ test).

$1.1 \times 10^{7}, 1.1 \times 10^{8}$, or $1.1 \times 10^{9}$ L. casei cells, and challenged with Listeria monocytogenes $\left(10^{6}\right.$ cells $) 2$ and 13 days after injection of $L$. casei. Livers were removed 2 days after listerial infection. In the liver of mice 2 days after administration of $1.1 \times 10^{9}$ of $L$. case $i$ cells, a large number of small to intermediate nodular infiltrations, consisting mainly of monocytes together with a few neutrophils, were observed in the sinusoids. Similar, but milder foci were observed in mice given $1.1 \times 10^{7}$ or $1.1 \times 10^{8} \mathrm{~L}$. casei cells. On the other hand, in the liver of mice 13 days after administration of $1.1 \times$ $10^{9} \mathrm{~L}$. case $i$ cells, intermediate to large epithelioid cell nodules, and a few monocytes were observed only inside or surrounding the nodules (Fig. 3). Histopathological changes after the administration of $1.1 \times 10^{7} \mathrm{~L}$. casei cells were nil. Forty-eight hours after the Listeria-induced infection, a number of bacterial clumps and necrosis were noted in the liver (Fig. 4). In contrast, when mice were infected with Listeria 2 days after the administration of $L$. casei, the bacterial clumps and necrosis of the hepatic cells had decreased, regardless of the dose of $L$. casei given. Histopathological manifestations in the liver of mice infected with Listeria 13 days after administration of $1.1 \times 10^{9} \mathrm{~L}$. case $i$ cells were similar to those in the liver of mice treated with $1.1 \times$ $10^{9}$ L. casei cells (non-infected mice), but bacterial clumps were absent (Fig. 5). The hepatic lesions of mice infected with Listeria 13 days after administration of 1.1 $\times 10^{7}$ L. casei cells were similar to those seen in the liver of mice infected with Listeria. 


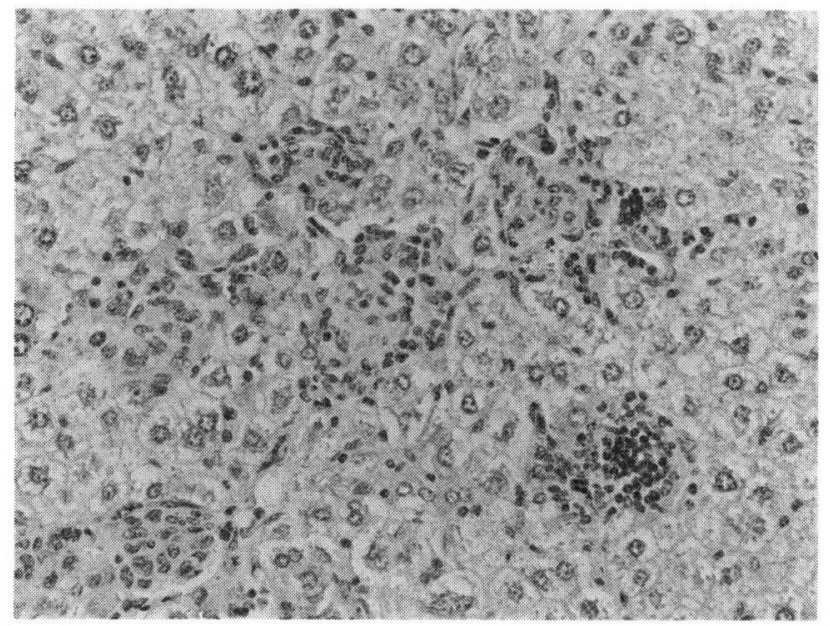

Fig. 3. Histopathological findings of the liver of mice 13 days after administration of L. casei $\left(1.1 \times 10^{9}\right)$. A large number of nodular infiltrative lesions consisting mainly of monocytes together with a few neutrophils are observed in the sinusoids, with irregular distribution to the lobules. Many epithelioid cells and a few typical monocytes are seen only inside or surrounding the nodules (hematoxylin and eosin stain; original magnification, $\times 200)$.

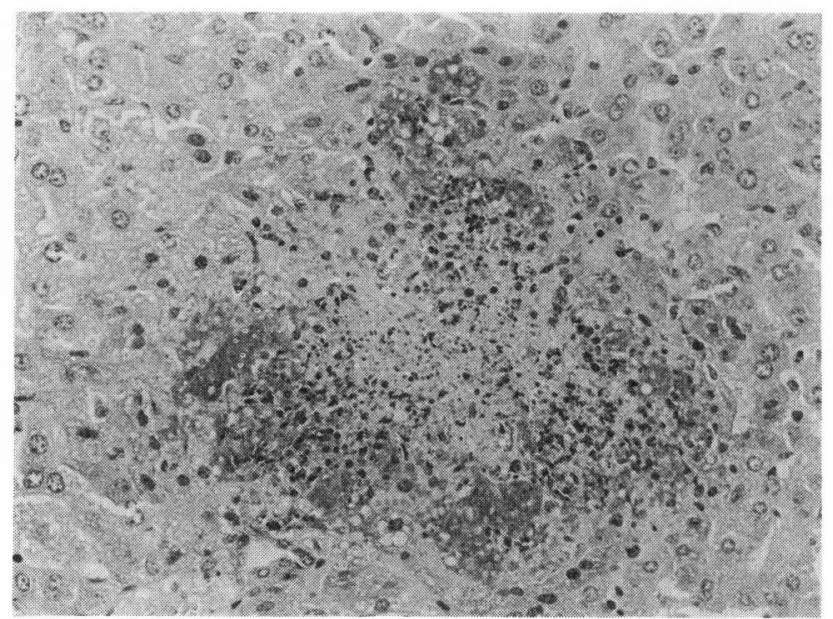

Fig. 4. Liver sample of mice $48 \mathrm{hr}$ after L. monocytogenes infection. Note the numerous bacterial clumps and necrosis of the hepatic cells (hematoxylin and eosin stain; original magnification, $\times 200)$.

The effects of carrageenan (CAR) on $L$. casei-mediated host resistance against listerial infection were studied (Table 3). Regardless of the timing of $L$. case administration ( -13 or -2 days), a smaller number of Listeria was found $10 \mathrm{~min}$ after infection in the liver of CAR-treated mice than in that of CAR-nontreated mice. 


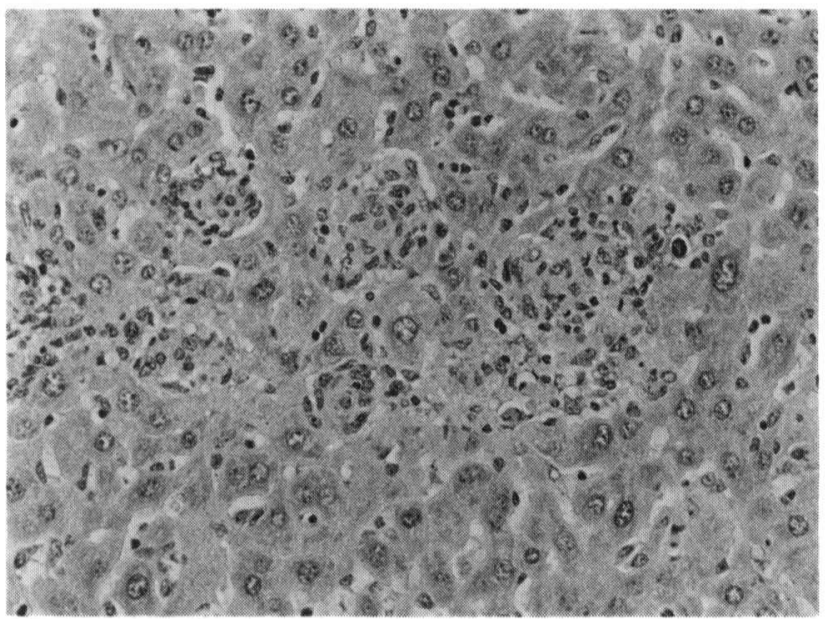

Fig. 5. Liver tissue from a mouse infected with $L$. monocytogenes 13 days after $L$. casei $\left(1.1 \times 10^{9}\right)$ administration. Note that changes are similar to those in Fig. 3 (hematoxylin and eosin stain; original magnification, $\times 200)$.

Table 3. Antagonistic effect of carrageenan on L. caseimediated enhancement of host resistance ${ }^{a}$ )

\begin{tabular}{|c|c|c|c|c|}
\hline \multirow{2}{*}{$\begin{array}{c}\text { L. casei } \\
\text { administration } \\
\text { at days before } \\
\text { infection }\end{array}$} & \multirow{2}{*}{$\begin{array}{c}\text { Carrageenan } \\
\text { treatment }\end{array}$} & \multicolumn{3}{|c|}{$\begin{array}{c}\log _{10} \text { no. of viable bacteria/liver at time } \\
\text { after infection }\end{array}$} \\
\hline & & $10 \mathrm{~min}$ & $6 \mathrm{hr}$ & $48 \mathrm{hr}$ \\
\hline \multicolumn{5}{|l|}{-2} \\
\hline- & - & $3.78 \pm 0.15$ & $2.53 \pm 0.12$ & $5.33 \pm 0.15$ \\
\hline- & + & $3.01 \pm 0.12^{b)}$ & $3.24 \pm 0.26$ & $6.25 \pm 0.30^{c)}$ \\
\hline+ & - & $3.68 \pm 0.08$ & $3.10 \pm 0.13$ & $3.23 \pm 0.18^{d)}$ \\
\hline+ & + & $3.21 \pm 0.20$ & $3.08 \pm 0.20$ & $6.10 \pm 0.24^{(c), e)}$ \\
\hline \multicolumn{5}{|l|}{-13} \\
\hline- & - & $3.50 \pm 0.02$ & $2.42 \pm 0.08$ & $5.18 \pm 0.14$ \\
\hline- & + & $2.80 \pm 0.11^{c)}$ & $3.29 \pm 0.29$ & $6.85 \pm 0.42^{c)}$ \\
\hline+ & - & $3.32 \pm 0.13$ & $1.07 \pm 0.14^{e)}$ & $1.94 \pm 0.30^{e)}$ \\
\hline+ & + & $2.90 \pm 0.15$ & $2.22 \pm 0.10^{b)}$ & $3.87 \pm 0.40^{b), e}$ \\
\hline
\end{tabular}

a) Mice were injected iv with $2.5 \times 10^{8}$ viable $L$. casei cells at 1 or 12 days before treatment with carrageenan $(4.5 \mathrm{mg})$. At $24 \mathrm{hr}$ after administration of carrageenan, mice were infected iv with $10^{4} L$. monocytogenes organisms. Values are expressed as mean \pm standard error $(n=4)$.

b) Significantly different from carrageenan-nontreated counterpart at $P<0.05$ (Student's $t$ test).

c) Significantly different from carrageenan-nontreated counterpart at $P<0.01$ (Student's $t$ test).

d) Significantly different from controls at $P<0.05$ (Student's $t$ test).

e) Significantly different from controls at $P<0.01$ (Student's $t$ test). 
Table 4. Subversion of $L$. casei-mediated enhancement of host resistance by X-ray irradiation ${ }^{a)}$

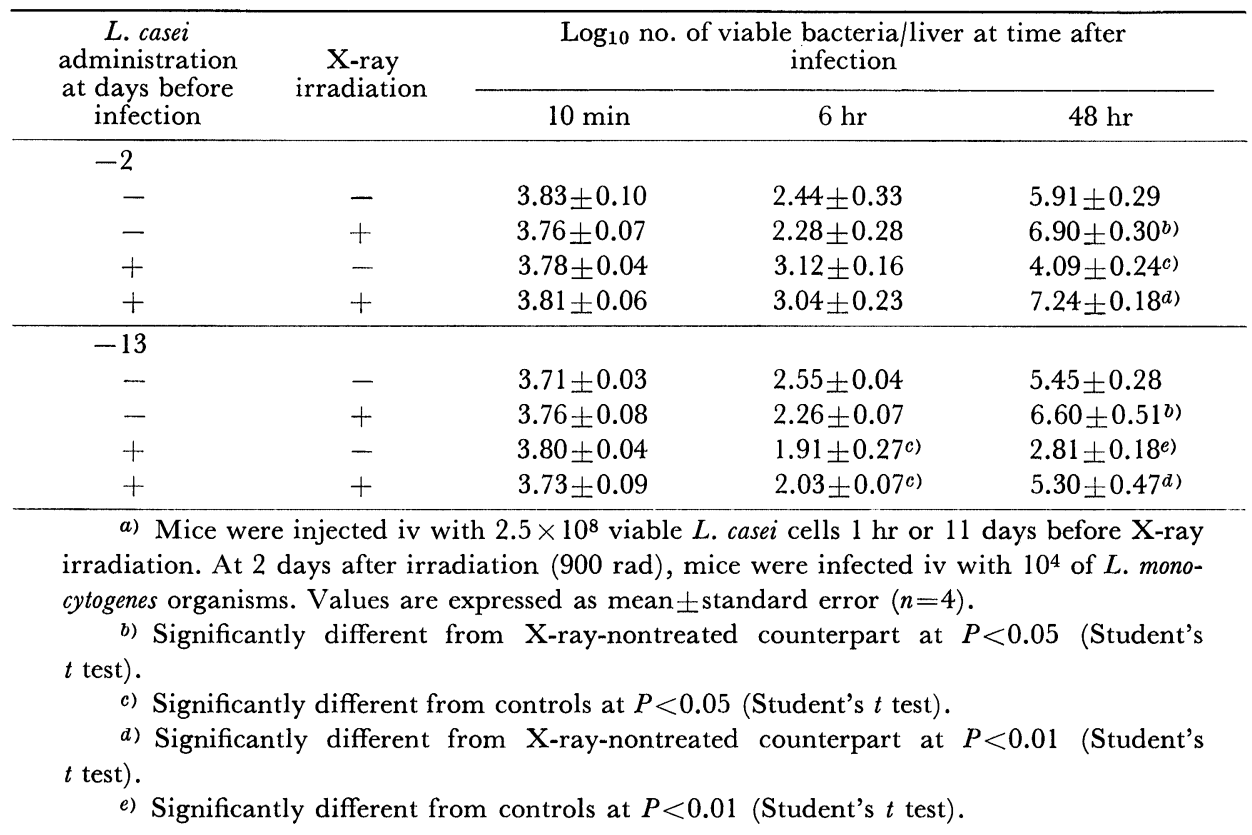

CAR treatment led to growth of Listeria $6 \mathrm{hr}$ after the infection (-13 days), and the growth of Listeria $48 \mathrm{hr}$ after infection in the L. casei-CAR-treated mice was enhanced in the 2- and 13-day groups, over the CAR-nontreated group.

The effects of X-ray irradiation on the $L$. casei-mediated host resistance against Listeria infection were studied (Table 4$)$. Trapping time $(10 \mathrm{~min})$ of the challenged Listeria by the liver and the killing of bacteria in the liver $6 \mathrm{hr}$ after infecting the mice with or without $L$. casei treatment were not affected by $\mathrm{X}$-ray irradiation. On the contrary, the markedly reduced multiplication effect of Listeria in the liver $48 \mathrm{hr}$ after infection by $L$. casei given at 2 and 13 days was all but completely abolished by $\mathrm{X}$-ray irradiation.

With respect to the enhancement of host resistance to Listeria infection that was seen 2 days after $L$. casei administration, the following considerations were made, based on these results. The administration of $1.1 \times 10^{7}$ or $1.1 \times 10^{8}$ of L casei cells failed to enhance the killing of Listeria in the liver at $6 \mathrm{hr}$ after infection but did suppress growth of Listeria $48 \mathrm{hr}$ after the infection.

Histopathological studies revealed that $L$. casei administration increased the number of macrophages in the liver after $L$. casei administration. The killing of Listeria $6 \mathrm{hr}$ after infection in L. casei $\left(2.5 \times 10^{8}\right.$ cells)-treated mice was not affected by X-ray irradiation or CAR treatment, but the inhibitory effect of $L$. casei on the multiplication of Listeria $48 \mathrm{hr}$ after infection was curtailed. Those findings indicate that enhancement of the $L$. casei-mediated host resistance to Listeria infection at this 
phase is mediated by non-specifically stimulated macrophages newly emigrating from the circulating blood to the liver (12-14) before and after Listeria infection but not fixed macrophages in the liver. When $1.1 \times 10^{9} \mathrm{~L}$. casei cells were given, there was a marked increase in the number of challenged Listeria. It seems that macrophages which phagocytosed numerous $L$. casei cells were unable to kill infecting Listeria, presumably due to depression of cell functions by overphagocytosis.

Concerning the enhancement of host resistance to Listeria infection seen around 13 days after the $L$. case $i$ administration, the following considerations were made. The administration of $L$. casei $\left(1.1 \times 10^{9}\right.$ cells $)$ enhanced the killing of Listeria in the liver $6 \mathrm{hr}$ after infection, and the growth of Listeria was suppressed by L. casei administration $\left(1.1 \times 10^{8}\right.$ or $1.1 \times 10^{9}$ cells $) 48 \mathrm{hr}$ after infection. The killing of Listeria $6 \mathrm{hr}$ after infection in $L$. casei-treated mice was not affected by X-ray irradiation but was suppressed by CAR treatment. In contrast, the inhibitory effect of $L$. casei on the Listeria multiplication $48 \mathrm{hr}$ after infection was inhibited by CAR treatment or by X-ray irradiation. Thus, the enhanced host resistance to Listeria infection at ca. 13 days after $L$. casei administration seems to be mediated not only by fixed macrophages but also by macrophages newly emigrating from the blood monocyte pool to the infection site (liver) in response to Listeria infection $(12,14)$. L. casei administration accelerated macrophage accumulation into the liver after Listeria infection. This may be explained in terms of the following experimental results. The number of peritoneal macrophages in mice given $L$. casei $\left(6.5 \times 10^{8}\right.$ cells $)$ iv. and 13 days later, injected ip with $10^{8} \mathrm{UV}$-killed $L$. monocytogenes was increased. $\left[{ }^{3} \mathrm{H}\right] \mathrm{TdR}$ incorporations in the liver DNA (Fig. 6$)$ before Listeria infection (0 hr) was markedly higher in mice given $L$. casei $\left(2.5 \times 10^{8}\right.$ cells $)$ than in $L$. casei-nontreated controls, but proceeded at almost the same rate in the two groups of mice during the first $6 \mathrm{hr}$ after infection. In contrast, $\left[{ }^{3} \mathrm{H}\right] \mathrm{TdR}$ incorporation in L. casei treated mice during 6 to $48 \mathrm{hr}$ after infection was much higher than in $L$. casei-nontreated mice. Histopathological studies revealed increased monocyte infiltration into the liver by $L$. casei administration 13 days before the Listeria infection. Epithelioid granulomas were formed in the liver 13 days after $L$. casei administration. Generally, it is thought that such formation can be ascribed to immunological reactions, and in some cases, delayed type hypersensitivity (DTH) reactions are required for formation $(1,10)$. Mitsuyama et al (11) mentioned that macrophages accumulating at the site of DTH reaction are important in the anti- $L$. monocytogenes host resistance. This finding supports the view that the accumulation and subsequent activation of liver macrophages in mice treated with $L$. casei are enhanced by lymphokines produced by $L$. casei-primed $\mathrm{T}$ cell.

The lack of increased resistance to Listeria infection 13 days after $5.5 \times 10^{7} \mathrm{~L}$. case $i$ cells can be explained as follows. Viable $L$. casei cells were no longer detectable in the liver (data not shown). Histopathologically, there was evidence of infiltration of macrophages into the liver, and the killing (6 hr) and growth suppression $(48 \mathrm{hr}$ ) of $L$. monocytogenes in the liver were slight. Therefore, macrophages related to the DTH reaction elicited by $L$. casei antigen do not seem to accumulate before infection. 


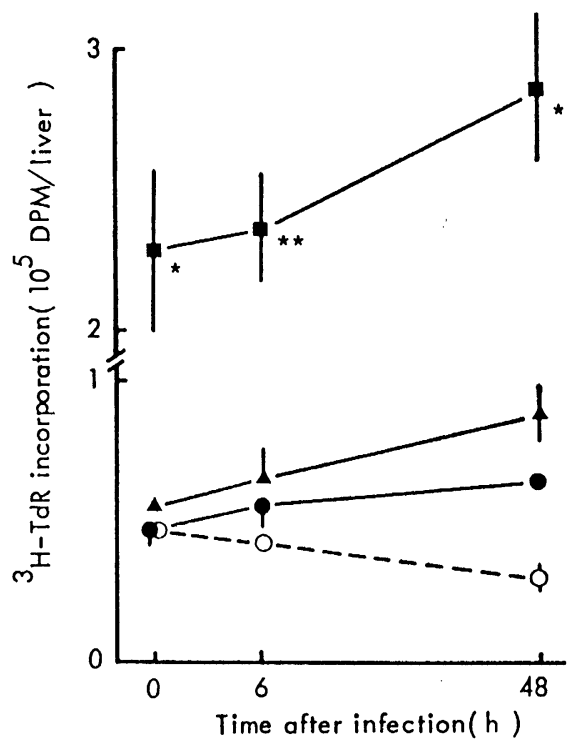

Fig. 6. Accumulation of macrophages labeled during infection in the liver. Mice were injected iv with $1.0 \times 10^{7}(\boldsymbol{\Delta})$ and $2.5 \times 10^{8}(\boldsymbol{\square})$ or without $(\boldsymbol{O})$ viable $L$. casei cells. After 13 days mice were given $10 \mu \mathrm{Ci}$ of $\left[{ }^{3} \mathrm{H}\right] \mathrm{TdR}$ iv. At $1 \mathrm{hr}$ after labeling, mice were infected iv with $8.4 \times 10^{3} \mathrm{~L}$. monocytogenes organisms, and the liver of mice was used for radiometry 0,6 , and $48 \mathrm{hr}$ after infection. As controls (O), the liver of mice $30 \mathrm{~min}$ and 6 and $48 \mathrm{hr}$ after injection of $10 \mu \mathrm{Ci}$ of $\left[{ }^{3} \mathrm{H}\right] \mathrm{TdR}$ without $L$. monocytogenes infection was used. Each symbol represents the mean \pm standard error $(n=3)$. The asterisks indicate significant difference between controls and $L$. casei-treated mice at levels of

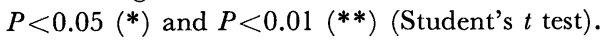

Activation of macrophages. The peritoneal exudate macrophage induced by intraperitoneal injection of $L$. casei was used as a model system to elucidate changes in cellular functions of liver macrophages due to intravenous injections of the agent.

Listericidal activity of mouse peritoneal macrophages was enhanced by administration of $L$. casei $\left(5 \times 10^{7}, 2.5 \times 10^{8}\right.$, or $1 \times 10^{9}$ cells) 13 days before harvest. In contrast, the activity of macrophages was reduced 2 days after L. casei administration, at three different doses, compared with that of resident macrophages. The phagocytic ability of macrophages against latex particles was elevated in peritoneal macrophages from mice treated with $L$. casei cells, irrespective of the timing $(-2$ of -13 days) of administration of the agent. Phorbol myristate acetate (PMA)-triggered respiratory burst $\left(\mathrm{O}_{2}\right.$ and $\left.\mathrm{H}_{2} \mathrm{O}_{2}\right)$ was elevated in all cases of $L$. casei administration. Lysosomal enzyme activities (acid phosphatase and $\beta$-glucuronidase) were significantly elevated in all cases of $L$. casei injections, irrespective of the dose and timing of the $L$. case $i$ administration, except for the $\beta$-glucuronidase activity of macrophages harvested 2 days after the $L$. casei administration. In contrast, alkaline phosphodiesterase activity was markedly reduced in all the $L$. casei-elicited macrophages, except for macrophages observed 2 days after the administration of $1 \times 10^{9}$ L. casei cells. 
The peritoneal macrophages 13 days after $L$. casei administration had a markedly elevated capacity of bactericidal activity against L. monocytogenes, PMA-induced respiratory burst and $\beta$-glucuronidase. Moreover, these macrophages also showed a remarkably lowered alkaline phosphodiesterase activity. These findings are known to correlate well to an "immunologically activated state" rather than to a "merely stimulated state" of a given macrophage. These results indicate an "immunological activation" of the RES (reticulo-endotherial system), such as the liver and spleen, at 13 days after intravenous administration of $L$. casei cells. There are marked differences in macrophage cellular functions related to their microbicidal mechanisms between macrophage populations induced by $L$. casei at 2 and 13 days after the administration. The former population may belong to "merely stimulated macrophages" with low antilisterial activity, whereas the latter may possess properties as "immunologically activated macrophages" with potent antilisterial activity.

Protective action of $\mathrm{L}$. casei cell fractions against Listeria infection. Cell fractions (cell wall, cytoplasm, polysaccharide, and peptidoglycan), prepared from Lactobacillus by Yokokura's method (25), were studied for their efficacies to enhance host resistance against $L$. monocytogenes infection.

Mice were given iv $1 \mathrm{mg}$ of each cell fraction of Lactobacillus 2 or 13 days before the intravenous infection of $L$. monocytogenes $\left(1 \times 10^{6}\right.$ cells $)$. A significant extension of survival time occurred in mice injected with the cell wall of $L$. casei (strains YIT 0003 and YIT 9018) 13 days before infection, compared to those given the other fractions of $L$. casei cells and $L$. plantarum and $L$. acidophilus cell fractions. The PMA-triggered respiratory burst of PECs in mice elicited by $L$. casei cell fractions was studied. The chemiluminescense (CL) of PECs $\left(1 \times 10^{6}\right.$ cells) elicited 2,7 , and 13 days after injection of cell fractions of $L$. casei $(1 \mathrm{mg}$ each) was higher in PEC induced by the cell wall than in PECs induced by other fractions, whereas the CL of PECs obtained 21 days after injection of those fractions was equal to that of normal PECs (on day 0). The PMN ratio (50\%) in PEC induced by the cellular fractions was higher than that in peritoneal cells and the CL in response to PMA was markedly elevated 2 days after injection of the cellular fractions. A considerable part of the apparent $\mathrm{CL}$ from the PEC at day-2 is thought to originate from contaminating PMN. The ratios of macrophages and PMN in the PECs at 7, 13, and 21 days after the injection of the cellular fractions were $50 \%$ to $80 \%$ and $1 \%$ to $6 \%$, respectively. The CL on these days is thought to be originated mainly from macrophages. The $\mathrm{O}_{2}{ }^{-}$production in response to PMA of peritoneal macrophages obtained 2 and 7 days after intraperitoneal injection of the cell wall was the highest among macrophages elicited by cellular fractions. Such a production in macrophages 13 and 21 days after injection of the cell wall was as high as that in the macrophages on 2 and 7 days, whereas it was much lower with the other cellular fractions. The $\mathrm{O}_{2}{ }^{-}$ production was elevated in macrophages elicited by the cell wall of $L$. casei and L. acidophilus, while the production in macrophages elicited by $L$. plantarum-cell wall was markedly lower than that of the other cell walls. In vitro listericidal activity of peritoneal macrophages was enhanced 7 and 13 days but was reduced 2 days after intraperitoneal injection of the cell wall fraction $(1 \mathrm{mg})$ of $L$. casei. The activity of 
L. acidophilus cell wall-induced peritoneal macrophages was reduced in all cases, regardless of the timing of the administration of the cell wall. When mice were treated with the cell wall of $L$. casei or $L$. acidophilus 2 days before the infection, growth of the Listeria during 6 to $48 \mathrm{hr}$ after infection was not suppressed. Reasons for the lack of anti-listerial action 2 days after the intravenous administration of $L$. case $i$ cell wall $(0.1,0.5$ or $1 \mathrm{mg})$ were not clear. Innate $L$. casei cells might be required for expression of the anti-listerial action.

Czuprynski et al (5) reported that increased mobilization of PMN and mononuclear phagocytes at the site of infection is of prime importance to protect the host against $L$. monocytogenes infection. In our experiment, increased numbers of PEC and PMN in PEC and in the resultant augmented $\mathrm{O}_{2}{ }^{-}$production of PEC 2 days after injection of $L$. casei cellular fractions were noted, whereas the host resistance to Listeria infection was not enhanced by preinjection of the fractions. This observation suggests that PMN are not effective in killing L. monocytogenes, in the host mouse. The PMA-triggered $\mathrm{O}_{2}^{-}$production of peritoneal macrophages was augmented by the intraperitoneal administration of $L$. casei- and $L$. acidophilus cell wall, but the in vivo bactericidal activity and the protective effect against Listeria infection was found only in the L. casei-cell wall. These findings are in agreement with data that

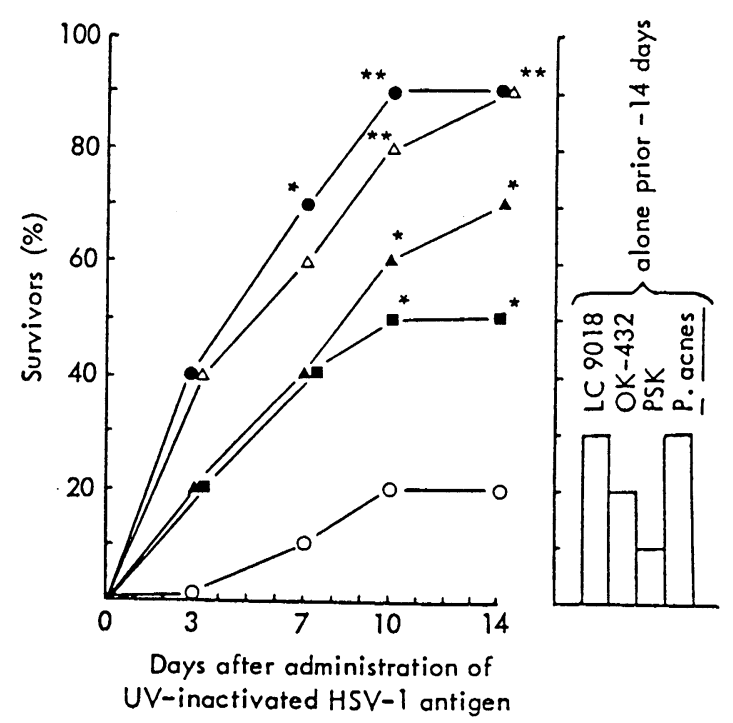

Fig. 7. Protection of mice pretreated with immunostimulants against HSV-1 infection according to the time of administration of UV-inactivated HSV-1 antigen. Mice $(n=$ 10) were injected ip with $0.2 \mathrm{ml}$ of each immunostimulant $(10 \mathrm{mg} / \mathrm{ml}) 14$ days before and with $0.1 \mathrm{ml}$ of UV-inactivated HSV-1 antigen $\left(5 \times 10^{7} \mathrm{PFUs} / \mathrm{ml}\right) 3,7,10$, or 14 days before ip challenge with $0.1 \mathrm{ml}$ of HSV-1 $\left(5 \times 10^{6} \mathrm{PFUs} / \mathrm{ml}\right)$. UV-inactivated HSV-1 antigen (UV-HSV-Ag) alone (O), LC9018+UV-HSV-Ag (•), OK-432+UV-

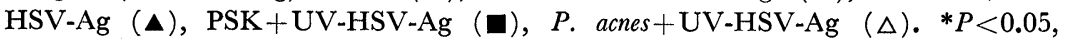
$* * P<0.01$. 
the protective activity against Listeria infection was enhanced only with whole cells of $L$. casei, among 10 species of lactobacilli (see p. 4). Almost all lactobacilli contain the teichoic acid moiety in their cell wall, but $L$. casei lacks such a moiety. Therefore, the anti-Listeria action of $L$. casei-cell wall might be mediated by specific components other than teichoic acid.

Enhancement of Host Resistance to Viral Infection by L. casei

The effects of immunostimulants such as LC9018 (8), OK-432 (17), PSK (24) and Propionibacterium acnes on fatal infection due to herpes simplex virus type 1 (HSV-1) in adult mice (26).

Protective action of immunostimulants against HSV-1 infection. Mice were given ip $2 \mathrm{mg}$ of LC9018 (a lyophilized preparation of heat-killed L. casei YIT9018), OK-432 (attenuated strain of Streptococcus pyogenes Su), PSK (a protein-bound polysaccharide extracted from Coriolus versicolor), or $P$. acnes (heat-killed at $80^{\circ} \mathrm{C}$ for $30 \mathrm{~min}$ ) 14 days before intraperitoneal challenge with HSV-1 $\left(5 \times 10^{5} \mathrm{PFUs} /\right.$ mouse $)$. No significant enhancement of resistance to HSV-1 infection in mice was seen after administration of these immunostimulants. However, the survival rate was somewhat higher in mice given LC9018 or $P$. acnes $(30-40 \%)$ than in the mice given OK-432 or PSK $(10-20 \%)$.

Effect of UV-inactivated HSV-1 antigen in combination with immunostimulants. Studies

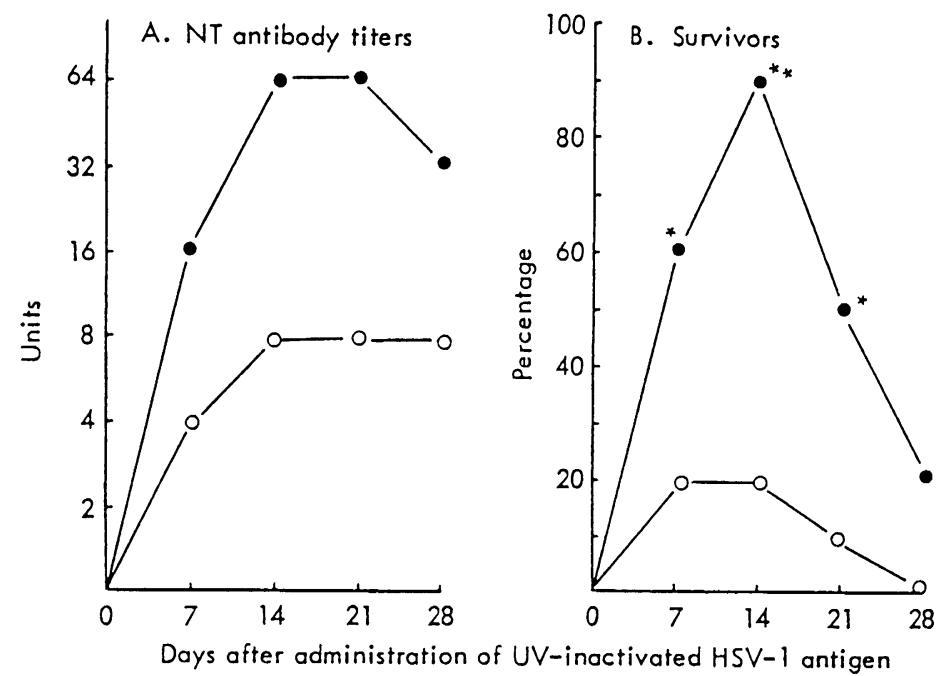

Fig. 8. Correlation between patterns of NT antibody titers and survival rates of mice pretreated with LC9018 in combination with UV-inactivated HSV-1 antigen. Mice were injected ip with $0.2 \mathrm{ml}$ of LC9018 $(10 \mathrm{mg} / \mathrm{ml}) 14$ days before and with $0.1 \mathrm{ml}$ of UV-inactivated HSV-1 antigen $\left(5 \times 10^{7} \mathrm{PFUs} / \mathrm{ml}\right) 7,14,21$, or 28 days before harvest of the blood samples for titration of serum NT antibody $(n=3)$ or ip challenge with $0.1 \mathrm{ml}$ of HSV-1 $\left(5 \times 10^{6} \mathrm{PFUs} / \mathrm{ml}, n=10\right)$. UV-inactivated HSV-1 antigen alone (O), LC9018+UV-inactivated HSV-1 antigen ( ). $* P<0.05, * * P<0.01$. 
were made of mice given immunostimulants ( $2 \mathrm{mg}$ each) ip 14 days before and UVinactivated HSV-1 antigen ip 3, 7, 10, or 14 days before infection with HSV-1 (Fig. 7). The survival rates of mice increased depending on the time of administration of the inactivated HSV-1 antigen. Maximum survival rates were noted 10 or 14 days after the administration of inactivated HSV-1 antigen in LC9018 (90\% on day 10$)$ and $P$. acnes $(90 \%$ on day 14$)$, followed by OK-432 (70\% on day 14$)$ and PSK (50\% on day 10). When mice were injected ip with LC9018 14 days before and with UV-inactivated HSV-1 antigen 3 days before the infection with HSV-1, the survival rate was $40 \%$, whereas serum neutralizing antibodies were not detectable at that time. It may be that the early phase protection of mice against HSV-1 infection after the administration of $L$. case $i$ is related to the increased natural killer cell cytotoxicity mediated by activated macrophages. The correlation between neutralizing antibody levels in serum and survival rates of mice given LC9018 in combination with UV-inactivated HSV-1 antigen was studied (Fig. 8). Neutralizing antibody levels in serum (A, ) showed maximum levels (64 units) 14 to 21 days after and were slightly reduced 28 days after (32 units) administration of inactivated HSV-1 antigen. The maximum survival rates $(\mathrm{B}, \mathbf{O})$ were observed 14 days after the administration of inactivated HSV-1 antigen (80\%); however, they were drastically reduced thereafter. Thus, correlation between patterns of neutralizing antibody titers and the number of survivors was nil. The phenomena may be due to changes in the IgG subclass and/or Fc receptors of effector cells.

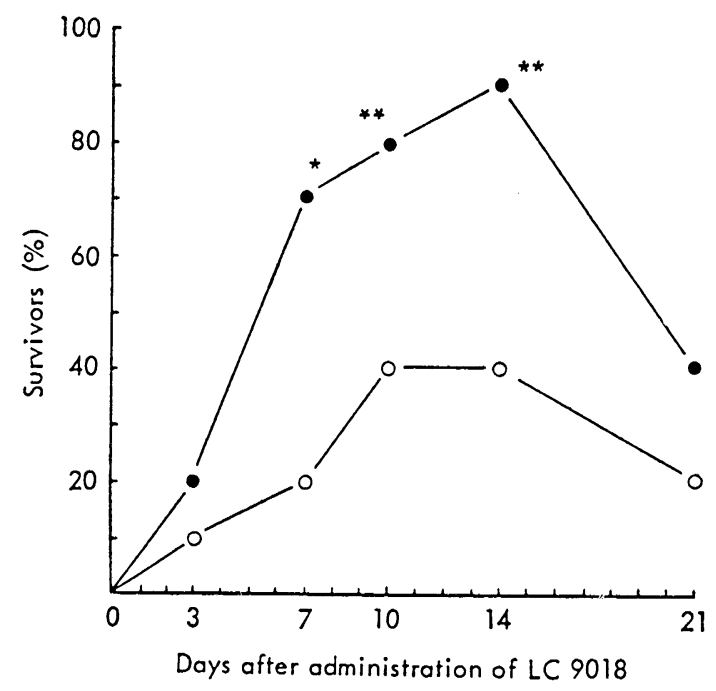

Fig. 9. Protection of mice pretreated with UV-inactivated HSV-1 antigen against HSV-1 infection according to the time of administration of LC9018. Mice $(n=10)$ were injected ip with $0.1 \mathrm{ml}$ of UV-inactivated HSV-1 antigen $\left(5 \times 10^{7} \mathrm{PFUs} / \mathrm{ml}\right) 14$ days before and with $0.2 \mathrm{ml}$ of LC9018 (10 mg/ml) 3, 7, 10, 14, or 21 days before challenge with $0.1 \mathrm{ml}$ of HSV-1 $\left(5 \times 10^{6} \mathrm{PFUs} / \mathrm{ml}\right)$. LC9018 alone (O), LC9018+UVinactivated HSV-1 antigen $(\bullet) .{ }^{*} P<0.05, * * P<0.01$. 
Effects of immunostimulants in combination with UV-inactivated HVS-1 antigen. Mice given UV-inactivated HSV-1 antigen 14 days before infection were injected with $2 \mathrm{mg}$ of $L$. casei at various intervals before the intraperitoneal infection with HSV-1 (Fig. 9). The survival rates of mice treated with inactivated HSV-1 antigen in combination with LC9018 were higher than those of mice given LC9018 alone and the highest rate was noted on day $14(90 \%)$. The correlation between neutralizing antibody levels in serum and survival rates of mice given UV-inactivated HSV-1 antigen in combination with $L$. casei was studied. Similar patterns were noted, as shown in Fig. 8. There was no correlation between the patterns of neutralizing antibody titers and the number of survivors 21 days after administration of $L$. casei (Fig. 10). There is probably a lack of function of the macrophage as a result of maturation or to the appearance of suppressor cells and/or suppressor factors.

Effects of transfer of PECs or spleen cells on HSV-1 infection in mice. Protection against on HSV-1 infection could be transferred to syngeneic recipient mice by the intraperitoneal injection of $\mathrm{PECs}$ from $\mathrm{C} 3 \mathrm{H} / \mathrm{He}$ mice treated with $\mathrm{LC} 9018$ alone and in combination with UV-inactivated HSV-1 antigen or with thioglycollate broth $18 \mathrm{hr}$ before intraperitoneal challenge with HSV-1. In contrast, there was no protective effect of spleen cells from mice treated with thioglycollate broth alone or with LC9018 in combination with thioglycollate broth (Tables 5 and 6). PECs induced by LC9018 alone also showed HSV-I focus formation-inhibiting ability
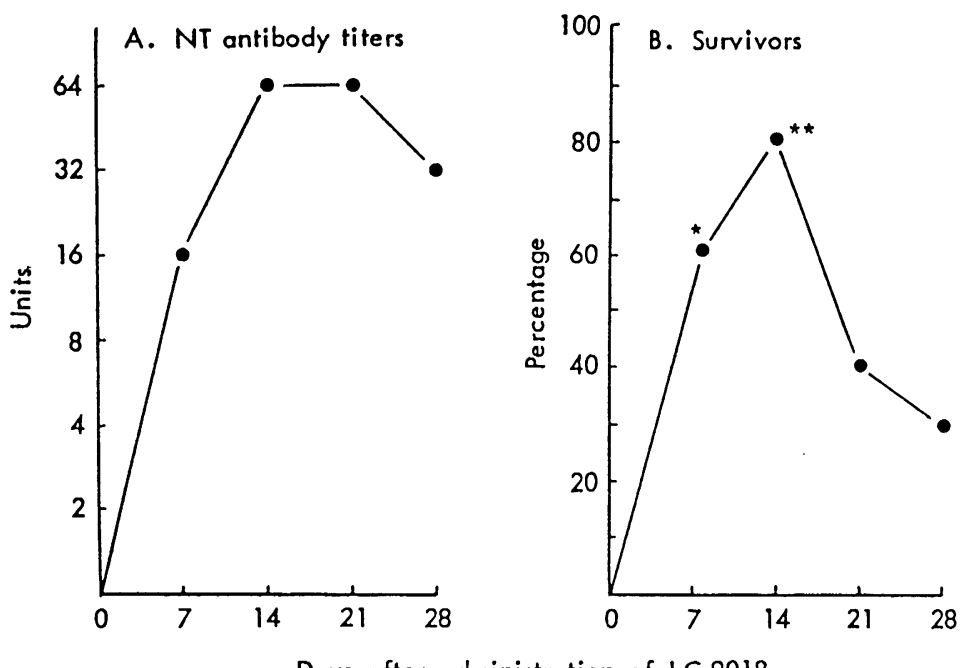

Fig. 10. Correlation between patterns of NT antibody titers and survival rates of mice pretreated with UV-inactivated HSV-1 antigen in combination with LC9018. Mice were injected ip with $0.1 \mathrm{ml}$ of UV-inactivated HSV-1 antigen $\left(5 \times 10^{7} \mathrm{PFUs} / \mathrm{ml}\right) 14$ days before and with $0.2 \mathrm{ml}$ of LC9018 $(10 \mathrm{mg} / \mathrm{ml}) 7,14,21$, or 28 days before harvest of the blood samples for titration of serum NT antibody $(n=3)$ or ip challenge with $0.1 \mathrm{ml}$ of HSV-1 $\left(5 \times 10^{6} \mathrm{PFUs} / \mathrm{ml}, n=10\right)$. ${ }^{*} P<0.05, * * P<0.01$. 
Table 5. Effects of transfer of PECs from mice treated with LC9018 alone or in combination with UV-inactivated HSV-1 antigen on HSV-1 infection ${ }^{a}$ )

\begin{tabular}{|c|c|c|c|c|}
\hline & \multicolumn{2}{|c|}{$\begin{array}{c}\text { No. of cells } \\
\text { transferred }\left(\times 10^{7}\right)\end{array}$} & \multicolumn{2}{|c|}{$\begin{array}{l}\text { Percentage of } \\
\text { survivors }\end{array}$} \\
\hline \multicolumn{2}{|l|}{ None } & - & \multicolumn{2}{|c|}{0} \\
\hline \multicolumn{5}{|l|}{ PECs from } \\
\hline \multicolumn{2}{|c|}{ Untreated mice } & 1.5 & \multicolumn{2}{|c|}{0} \\
\hline \multicolumn{2}{|c|}{ LC9018-treated mice } & 1.0 & \multicolumn{2}{|c|}{40} \\
\hline \multicolumn{2}{|c|}{$\begin{array}{l}\text { (LC9018 + UV-inactivated } \\
\text { HSV-1 antigen)-treated mice }\end{array}$} & 1.0 & \multicolumn{2}{|c|}{40} \\
\hline \multicolumn{5}{|c|}{$\begin{array}{l}\text { a) PECs were harvested } 14 \text { days after the simultaneous administration (ip) } \\
\text { LC } 9018(2 \mathrm{mg}) \text { and UV-inactivated } \mathrm{HSV}-1 \text { antigen }\left(5 \times 10^{6} \mathrm{PFUs}\right) \text {, and } \\
\text { nsferred into the peritoneal cavities of syngeneic recipient } \mathrm{C} 3 \mathrm{H} / \mathrm{He} \text { mice. } \\
\left.\text { ce were injected ip with HSV-1 ( } 5 \times 10^{5} \mathrm{PFUs}\right) 18 \mathrm{hr} \text { after transfer. }\end{array}$} \\
\hline \multicolumn{5}{|c|}{$\begin{array}{l}\text { Table } 6 . \text { Effects of transfer of spleen cells or PECs from mice treated with } \\
\text { thioglycollate alone or in combination with LC9018 on HSV-1 infection }\end{array}$} \\
\hline & \multicolumn{2}{|c|}{$\begin{array}{c}\text { No. of cells } \\
\text { transferred }\left(\times 10^{7}\right)\end{array}$} & Route & $\begin{array}{l}\text { Percentage of } \\
\text { survivors }\end{array}$ \\
\hline \multirow[t]{2}{*}{ None } & \multicolumn{2}{|l|}{-} & iv & 0 \\
\hline & \multicolumn{2}{|l|}{-} & ip & 0 \\
\hline \multirow[t]{2}{*}{ Thioglycollate alone } & Spleen cells & 16 & iv-iv & 0 \\
\hline & PEC & 0.9 & ip-ip & 0 \\
\hline \multirow[t]{2}{*}{ LC9018+thioglycollate } & Spleen cells & 16 & iv-iv & 0 \\
\hline & PECs & 0.9 & ip-ip & 40 \\
\hline
\end{tabular}

a) Syngeneic recipient mice were injected iv or ip with spleen cells or PECs harvested from syngeneic donor mice 14 and 4 days after ip administration of LC9018 $(2 \mathrm{mg})$ and thioglycollate broth $(2 \mathrm{ml})$, and injected iv or ip with HSV-1 $\left(5 \times 10^{5}\right.$ PFUs $) 18 \mathrm{hr}$ after transfer.

in vitro, whereas focus formation was not inhibited by thioglycollate-elicited PECs, which exhibited high phagocytic activity. These findings suggest that the enhancement of resistance to HSV-I infection in mice by the administration of $L$. casei in combination with UV-inactivated HSV-I antigen is mediated mainly by activated macrophages.

Acknowledgements. I thank H. Tomioka, T. Watanabe, K. Sato, T. Kitagawa, T. Yokokura, K. Asano and N. Murai for cooperation with these investigations.

\section{REFERENCES}

(1) Adams, D.O. 1976. The granulomatous inflammatory response. Am. J. Pathol. 84: 164-191.

(2) Balow, J.E., and A.S. Rosenthal. 1973. Glucocorticoid suppression of macrophage migration inhibitory factor. J. Exp. Med. 137: 1031-1041.

(3) Bekierkunst, A. 1976. Stimulation of lymphocyte proliferation by killed mycobacteria and other bacterial species. Infect. Immun. 14: 28-32.

(4) Bloksma, N.E., E. DeHeer, H. Van Dijk, and J.M. Willers. 1979. Adjuvanticity of lactobacilli. I. Differential effects of viable and killed bacteria. Clin. Exp. Immunol. 37: 367-375.

(5) Czuprynski, C.J., P.M. Henson, and P.A. Campbell. 1984. Killing of Listeria monocytogenes by 
inflammatory neutrophils and mononuclear phagocytes from immune and nonimmune mice. J. Leukocyte Biol. 35: 193-208.

(6) Galleli, A., Y. Le Garrec, and L. Chedid. 1981. Increased resistance and depressed delayed-type hypersensitivity to Listeria monocytogenes induced by pretreatment with lipopolysaccharide. Infect. Immun. 31: 88-94.

(7) Glasgow, L.A., J. Fischbach, S.M. Bryant, and E.R. Kern. 1977. Immunomodulation of host resistance to experimental viral infections in mice: effects of Corynebacterium acnes, Corynebacterium parvum, and Bacille Calmette-Guérin. J. Infect. Dis. 135: 763-770.

(8) Kato, I., S. Kobayashi, T. Yokokura, and M. Mutai. 1981. Antitumor activity of Lactobacillus casei in mice. Gann 72: 517-523.

(9) Mackaness, G.B. 1969. The influence of immunologically committed lymphoid cells on macrophage activity in vivo. J. Exp. Med. 129: 973-992.

(10) McGee, M.P., Q.N. Myrvik, and E.S. Leake. 1978. Organization of allergic granulomas and dependence on insoluble antigen. J. Reticuloendothel. Soc. 24: 253-262.

(11) Mitsuyama, M., K. Nomoto, and K. Takeya. 1982. Direct correlation between delayed footpad reaction and resistance to local bacterial infection. Infect. Immun. 36: 72-79.

(12) Mitsuyama, M., K. Takeya, K. Nomoto, and S. Shimotori. 1978. Three phases of phagocyte contribution to resistance against Listeria monocytogenes. J. Gen. Microbiol. 106: 165-171.

(13) Newborg, M.F., and R.J. North. 1980. On the mechanism of T cell-independent anti-Listeria resistance in nude mice. J. Immunol. 124: 571-576.

(14) North, R.J. 1970. The relative importance of blood monocytes and fixed macrophages to the expression on cell-mediated immunity to infection. J. Exp. Med. 132: 521-534.

(15) North, R.J. 1971. The action of cortisone acetate on cell-mediated immunity to infection: suppression of host cell proliferation and alteration of cellular composition of infective foci. J. Exp. Med. 134: 1487-1500.

(16) North, R.J. 1974. T cell dependence of macrophage activation and mobilization during infection with Mycobacterium tuberculosis. Infect. Immun. 10: 66-71.

(17) Okamoto, H., M. Minami, and S. Shoin. 1966. Experimental anticancer studies. Part 1. On the streptococcal preparation having potent anticancer activity. Jpn. J. Exp. Med. 36: 175-186.

(18) Osada, Y., M. Mitsuyama, K. Matsumoto, T. Une, T. Otani, H. Ogawa, and K. Nomoto. 1982. Stimulation of resistance of immunocompromised mice by a muramyl dipeptide analog. Infect. Immun. 37: 1285-1288.

(19) Saito, H., H. Tomioka, and K. Sato. 1983. Effect of streptococcal preparation, OK-432, on experimental infection due to Mycobacterium lepraemurium in mice of $\mathrm{C} 3 \mathrm{H} / \mathrm{Jms}$ strain. Hiroshima J. Med. Sci. 32: 231-234.

(20) Saito, H., T. Watanabe, and Y. Horikawa. 1986. Effects of Lactobacillus casei on Pseudomonas aeruginosa infection in normal and dexamethasone-treated mice. Microbiol. Immunol. 30: 249259.

(21) Saito, H., T. Watanabe, T. Kitagawa, and K. Asano. 1985. Protective effects of bacterial immunostimulants, OK-432 and LC 9018 on Pseudomonas aeruginosa infection in tumor-bearing mice. Hiroshima J. Med. Sci. 34: 459-462.

(22) Sato, K. 1984. Enhancement of host resistance against Listeria infection by Lactobacillus casei: role of macrophages. Infect. Immun. 44: 445-451.

(23) Swartzberg, J.E., J.L. Krahenbuhl, and J.S. Remington. 1975. Dichotomy between macrophage activation and degree of protection against Listeria monocytogenes and Toxoplasma gondii in mice stimulated with Corynebacterium parvum. Infect. Immun. 12: 1037-1043.

(24) Tsukagoshi, S., and F. Ohashi. 1974. Protein-bound polysaccharide preparation, PSK, effective against mouse sarcoma-180 and rat ascites hepatoma AH-13 by oral use. Gann 65: 557-558.

(25) Yokokura, T. 1971. Phage receptor material in Lactobacillus casei cell wall. I. Effect of L-rhamnose on phage adsorption to the cell wall. Jpn. J. Microbiol. 15: 457-463.

(26) Watanabe, T., and H. Saito. 1986. Protection of mice against Herpes simplex virus infection by a Lactobacillus casei preparation (LC 9018) in combination with inactivated viral antigen. Microbiol. Immunol. 30: 111-122. 